\title{
Incorporating E-assessment tools in teaching for effective and authentic assessment.
}

\author{
S.B. Sangle ${ }^{1}$, K.N. Nandurkar ${ }^{2}$, P.J. Pawar ${ }^{3}$ \\ ${ }^{1}$ Assistant Professor, Department of Production Engineering, K.K. Wagh Institute of Engineering Education and \\ Research, Nashik, Maharashtra, India. \\ ${ }^{2}$ Principal and Professor, Department of Production Engineering, K.K. Wagh Institute of Engineering Education and \\ Research, Nashik, Maharashtra, India. \\ ${ }^{3}$ Head of the Department and Professor, Department of Production Engineering, K.K. Wagh Institute of Engineering \\ Education and Research, Nashik, Maharashtra, India \\ ${ }^{1}$ sbsangle@kkwagh.edu.in
}

\begin{abstract}
Throughout most of the 20th century, classroom assessment was considered as mechanism for providing an index of learning, and it followed a predictable pattern: teachers taught, tested the students' knowledge of the material, made judgements about students' achievement based on the testing, and then moved on to the next unit of work. But this conventional assessment technique has some limitations. The teacher gets feedback of his teaching and diagnosis of student learning at the end of semester. To overcome this, many teachers now adapting the formative assessment to get the instant feedback of his teaching as well as student learning. When we have to go for formative assessment by conventional pen and paper method it takes a lot of time and also teacher has to analyse the input's obtained from the student, this may reduce teacher efficiency and increase the chances of faulty output. In this situation the E- assessment tools come as an effective solution for this problem. The present study investigates the use of different e-assessment tools to overcome the conventional assessment problems. The study describes the details of effective incorporation different open source tools like Edmodo, Edpuzzle, Polls everywhere, testmoz and rubistar in teaching. The use of this tools help to enhance the efficiency of teacher, understanding level of students as well as academic results for the concern subject. The case study of Implementation of Edmodo tool for soft skill subject indicates the noticeable improvement in the PO attainment.
\end{abstract}

Keywords: E-assessment, rubistar, Polls everywhere.

\section{Introduction}

To assist in the construction, delivery, storage or reporting of student assessment tasks, responses, grades or feedback is essential. E-assessment can be undertaken with many devices, such as traditional desktop computers or laptops, with portable communication devices such as smart mobile phones, with digital devices such as iPads or through the use of electronic gaming devices. E-assessment can use multitude of formats, including text documents or portable document formats, multimedia formats such as sound, video or images; it can involve complex simulations or games; it can also be undertaken by students in groups or individually and it can occur with large numbers of students in a synchronous or asynchronous manner. Teachers can use computers to construct their assessment tasks, to deliver these tasks to the relevant students and to record and provide feedback and grades to these students. Computers can also be used to analyse the students' responses, both to provide feedback to the student on the quality and relevance of their response, as well as to provide feedback to the teacher on whether the task can differentiate between students with different abilities. E-assessment can be used to test many different capabilities and skills that are developed by students (Kavitha et al., 2018). There are only a few tasks that might not be suitable for completing and recording electronically, but the number of such tasks is rapidly diminishing as technology becomes more sophisticated and widespread. In many disciplines laboratory equipment can be manipulated remotely and students can undertake real time physical performances that are able to be recorded and used for assessment purposes. We are quickly approaching the stage where our imaginations will be the limiting factor in designing eassessment.

There are four basic types of assessments which can be set for students - diagnostic, formative, integrative or summative.

\section{A. Diagnostic assessment}

This is often the most underused of the traditional assessment formats in tertiary education and is too often associated with a negative model designed to identify deficiencies in students' capabilities (Benseman et al., 2008). This situation should be changed so that diagnostic assessments are incorporated as an initial component in all courses and are seen as a means of encouraging students' ownership of their learning and assessment. Low stakes diagnostic tasks would establish a baseline for standards within a course; they would allow students to determine their preparedness for their current learning activities and allow teachers to adjust their introductory learning activities so that the majority of the students are able to participate at a meaningful level. Diagnostic assessment 
tasks also highlight for students the core principles and key concepts that are critical for the learning they are about to undertake.

\section{B. Formative assessment}

The tasks with timely and appropriate feedback should be used throughout a course; these tasks are primarily intended to have an impact on the current learning of students and most often use feedback to connect the formative task to potential improvements in student performance in subsequent summative tasks. Usually the formative assessment is predominantly about improving learning, whether or not improvements are seen in subsequent summative tasks; however, students often view their performance in summative tasks as a measure of how much they have learnt within a course.

\section{Summative assessment}

The tasks are used primarily for progression and certification purposes, as well as a proxy measure of overall learning.

\section{Integrative assessments}

This are designed to promote and measure student selfregulation and the capabilities associated with lifelong learning (Crisp, 2012). Marks and grades could be used in integrative assessments as indicators of standards, even if they are not used to make decisions about progression and certification. Integrative tasks can be for formative or summative purposes. The advantage of identifying an assessment task as being integrative would be the highlight that the primary purpose of the task is to provide feedback (or judgement) on students' abilities to be self-regulated learners. They are expected to identify and use standards and to apply their learning to future situations by being able to articulate their strategies or decisions in responding to a task or situation. Judgements and feedback on these integrative tasks can come from any combination of the teacher, the student or peers. The key characteristic of integrative assessment is that its primary purpose is to influence students' approaches to future learning.

Integrative assessments have the following characteristics:

- students are provided with opportunities to make judgements about their own learning or performance through review and critique;

- students are provided with opportunities to define standards and expectations in their response;

- students are provided with opportunities to track and analyse their approaches to responding to a problem, issue, situation or performance;

- students are provided with opportunities to integrate prior or current feedback into their response;

- students are provided with opportunities to engage with a meaningful task that has inherent worth beyond just an assessment activity;

- students are rewarded for the quality of their analysis of metacognitive abilities, rather than declarative knowledge.

\section{E-assessment tools}

There are many open source E-assessment tools available online which are very effective and efficient such as

- Polls-everywhere

- Edmodo

- Edpuzzle

- Testmoz

- Rubistar

Present study will provides stepwise operating procedure of these tools.

\section{A. Polls-everywhere}

Poll Everywhere is a free tool for creating questions for formative assessment during the class sessions. The teacher creates a poll (using variety of questions: MCQ, Word Cloud, QA, Rank Order etc.) The link of the poll is sent to students on wants-app or by email. They attempt the poll the result of which can be seen by all students on screen in the class immediately.

Step:1 Create an account on polls-everywhere Go to https://www.polleverywhere.com

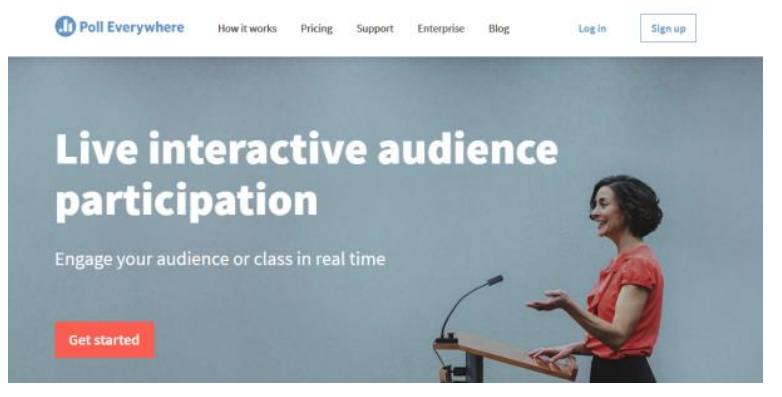

Fig 1.1 Home page of Polls-everywhere

Step:2 Click on + sign for creating new poll There are many choices MCQ, Word Cloud, Rank Order etc.

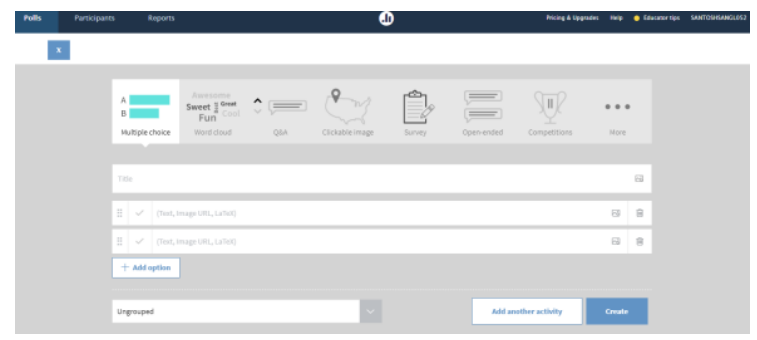

Fig. 1.2 Different types of formative questions.

Step:3 MCQ is selected. Prepare question and add alternatives. Click on Create 


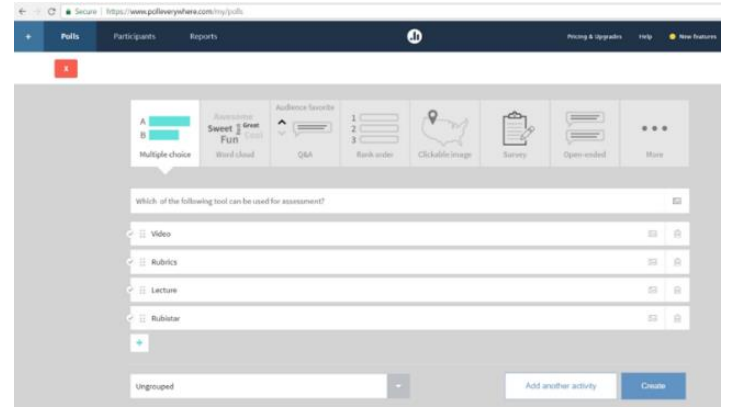

Fig. 1.3 Constructing the question.

Step:4 Once created the Question looks like this. Link is created and shown on the top of the poll. Copy -paste and send to students

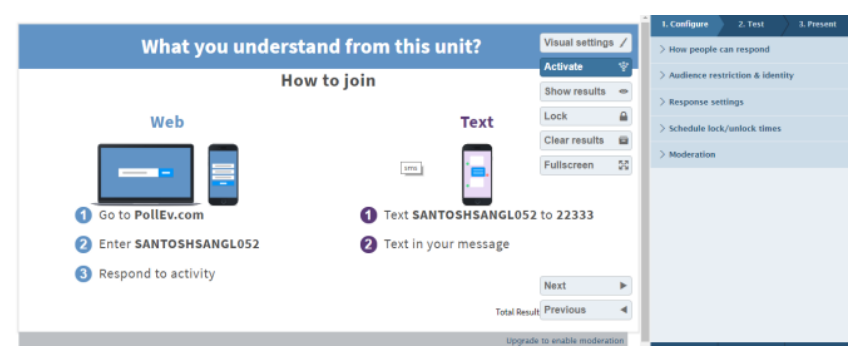

Fig. 1.4 Publishing the poll.

Step:5 Link is created and shown under "How people can respond" to the poll.

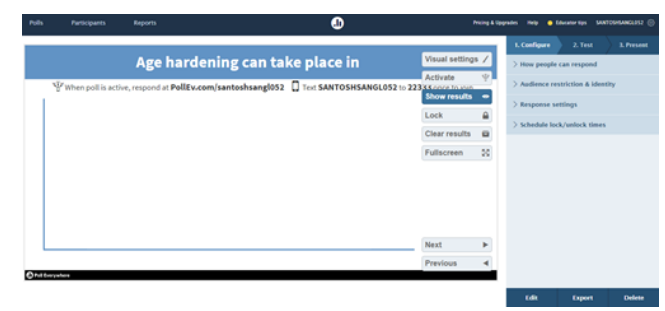

Fig. 1.5 Live responses window.

Step:6 Once the link is sent to the students, activate the Poll.

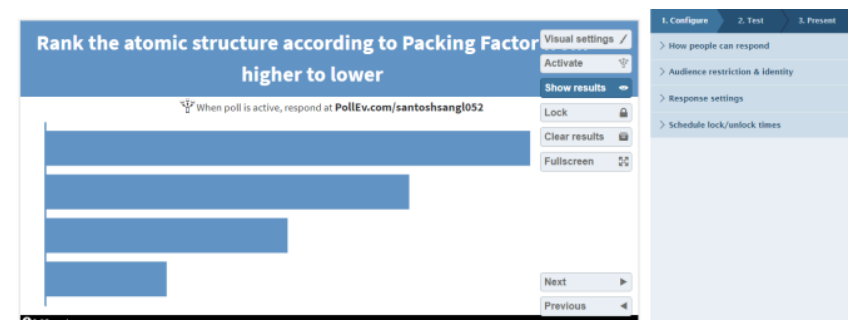

Fig. 1.6 Choices selected by student.

Step:7 The Word Cloud created by student responses will look like this.

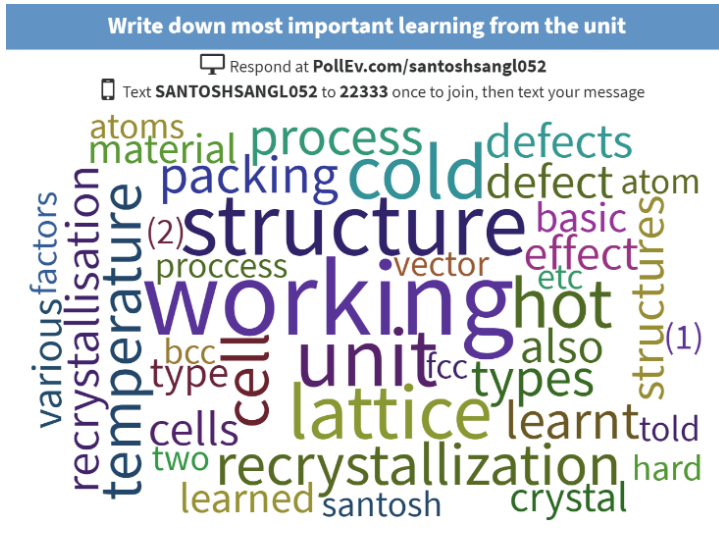

Fig. 1.7 Word cloud generated for material science subject.

\section{B. Edmodo}

Edmodo is a free social learning platform that provides a safe way for teachers to communicate and engage with students, parents, and other teachers. On Edmodo, teachers are at the centre of a powerful network that connects them with the people and resources they need to teach more.

Step 1 Create an account on Edmodo Go to https://www.edmodo.com/

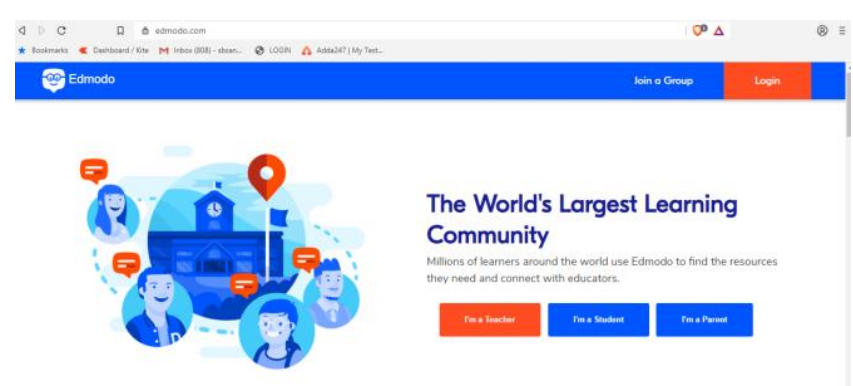

Fig. 2.1 Home page of Edmodo

Fill out your teacher profile. Upload a photo, add office hours, and share a little about yourself with your students, parents, and colleagues

Step 2: Create a Class Classes on Edmodo are a great way to get your classroom connected and increase sharing, participation, and self-expression - all in a private, closed setting.

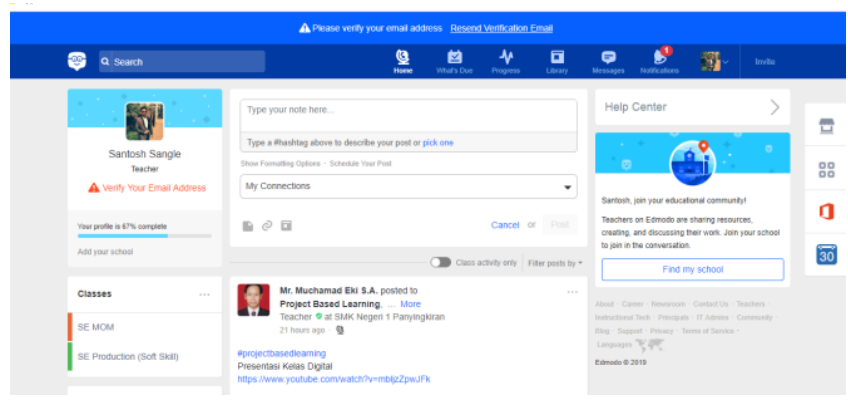

Fig. 2.2 Profile view of Teacher 
Step 3: Invite Students and Parents to Join Your Classes When students and parents join your Classes; everyone becomes more engaged.

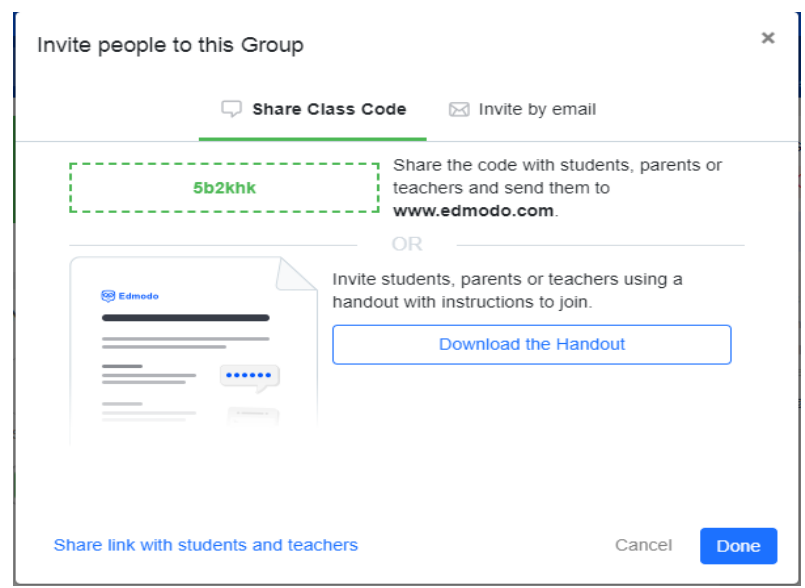

Fig. 2.3 Invitation for student to join the class

Step 4: Update the activity for student like share the videos, quiz, and much more

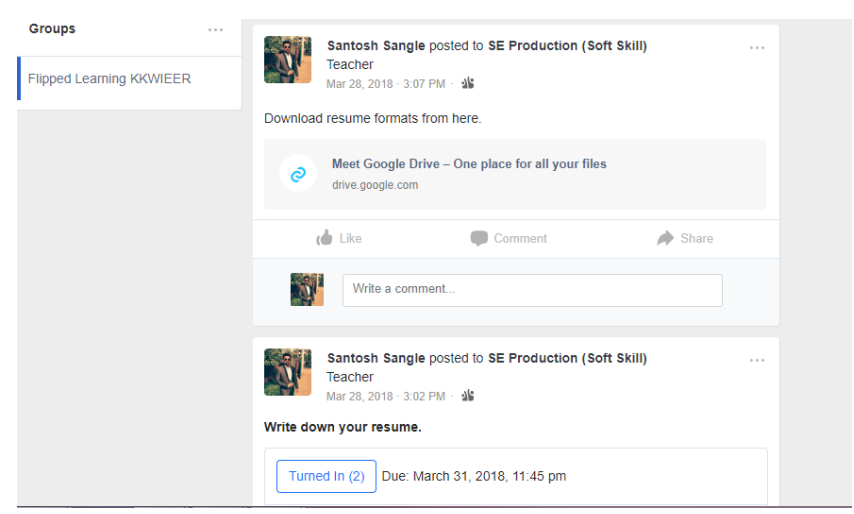

Fig. 2.4 Uploading of assignment

Step 5: See results of assignment and give comment on particular assignment to the student.

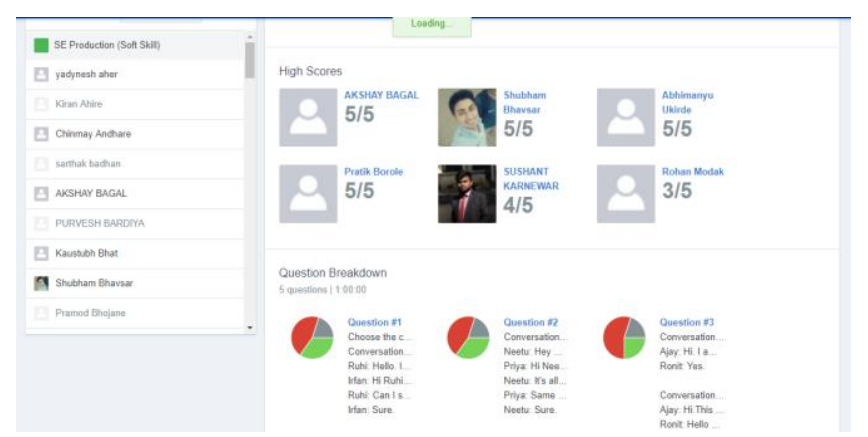

Fig. 2.5 Grades of Assignment

\section{Edpuzzle}

Learning through the e content is very popular now a day. But assessment and engagement of student to the video lectures is typical problem. To solve this problem Edpuzzle is free platform available Make any video for your lesson
Choose a video, give it your magic touch and track your students' comprehension.

Step 1: Go to the https://edpuzzle.com/

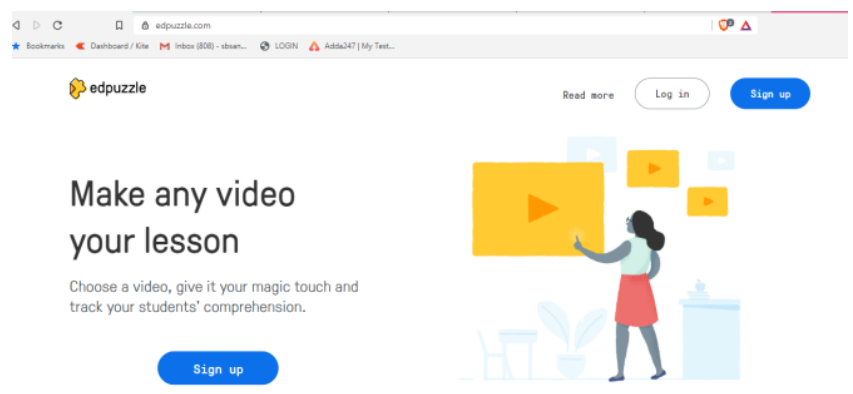

Fig. 3.1 Home page of Edpuzzle

Step 2: select the video from the large number of resources.

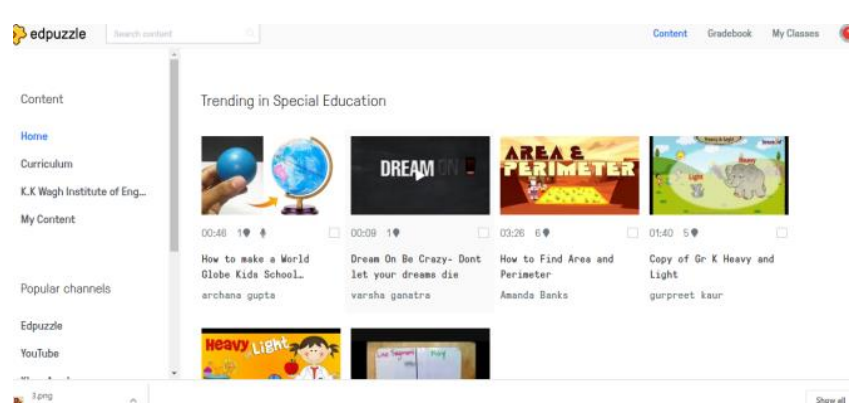

Fig. 3.2 Selection of video from different resources.

Step 3: Edit the video add your voice, add question in video, crop the main part of video and much more.

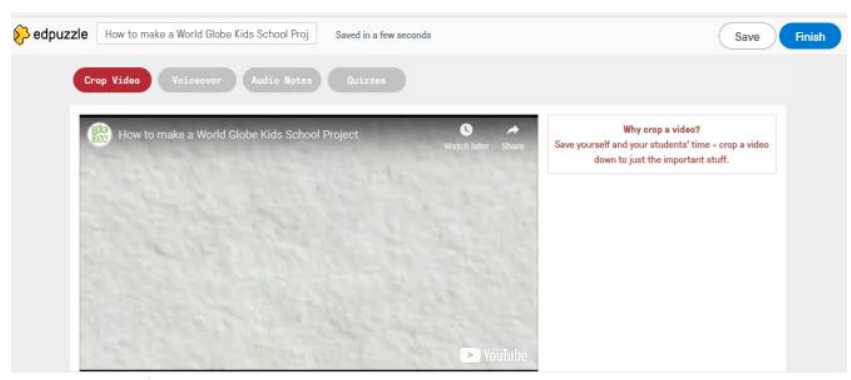

Fig. 3.3 Editing of video.

Step 4: Assign this video to the class and track the record of student by getting the result in different formats

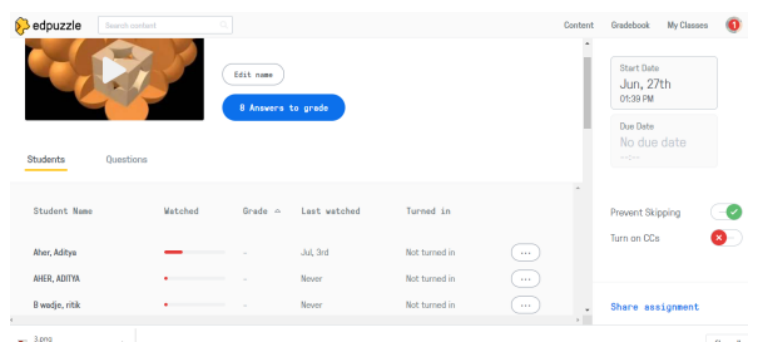

Fig. 3.4 Assessment sheet of student. 


\section{Testmoz}

Testmoz is a free tool for creating quiz and administering it to students. It creates a Code for each Quiz and the user has to use that code. On submission, the teacher gets the report of each student's attempt and scores for each item in the quiz. It also creates a report of all students in the class for each question in the Quiz.

\section{Step:1 Go to https://testmoz.com}

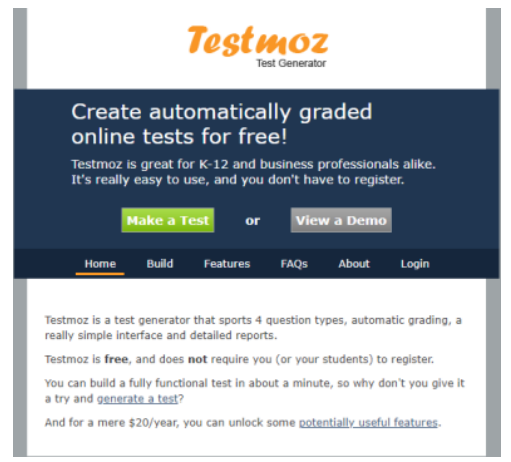

Fig. 4.1 Homepage of Testmoz

Step: 2 Write down the test name and password

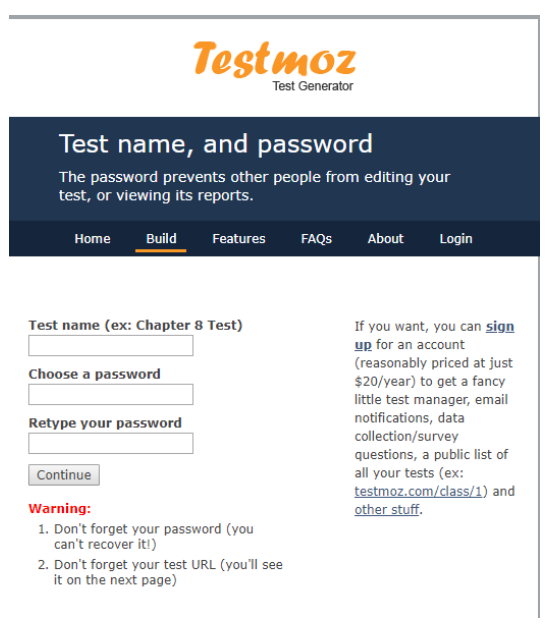

Fig. 4.2 Test generation

Step:3 Select the question type and Write down the questions Question types available:

- MCQ

- True or False

- Filling the blank

- Diagram based questions etc.

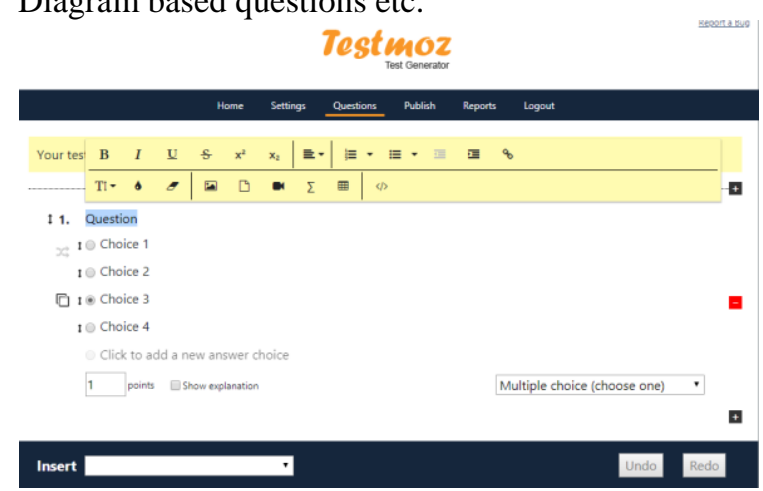

Fig. 4.3 Types of questions
Step: 4 Publish the Quiz The link with the code is sent to students

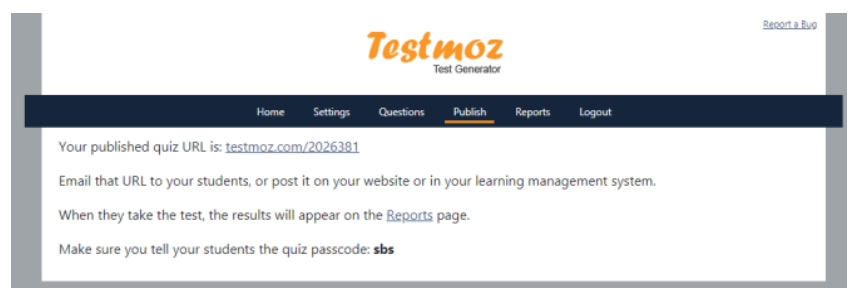

Fig. 4.4 Publishing your test for student.

Step: 5 Report is generated in two parts Each Student Score Whole class sore with question grid.

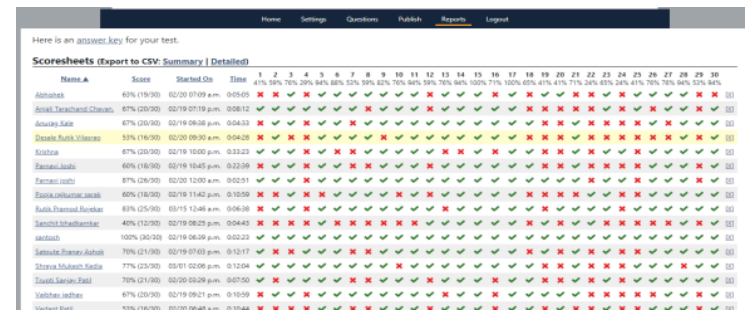

Fig. 4.5 Analysis of test result.

E. RubiStar

RubiStar is a free tool to help teachers create quality rubrics.

Step: 1 Go to the http://rubistar.4teachers.org

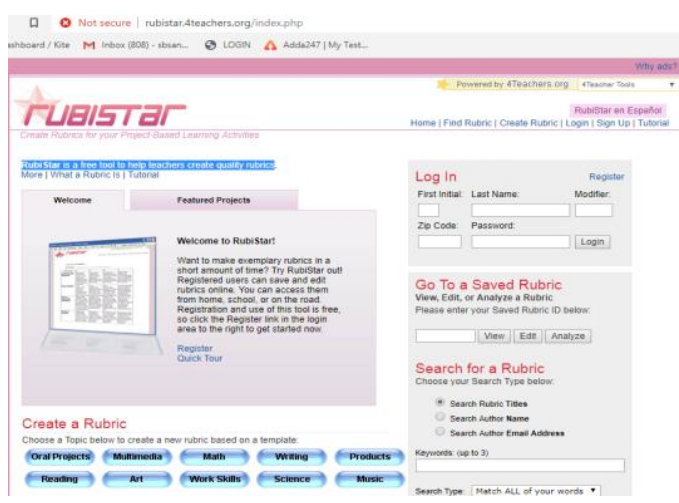

Fig. 5.1 Homepage of RubiStar

Step: 2 Search for a readymade rubric or create new rubric for assessing a content / skill from your subject. Share the link of that rubric on discussion forum in Moodle.

Rubric ID: 2804529

Find out how to make this rubric interactive

Assignment rubrics

\begin{tabular}{|c|c|c|c|c|c|}
\hline CATEGORY & $8-10$ & $6-8$ & $4-6$ & $2-4$ & $0-2$ \\
\hline $\begin{array}{l}\text { Timely completion } \\
\text { of assignment }\end{array}$ & $\begin{array}{l}\text { If student } \\
\text { perform the } \\
\text { practical with } \\
\text { accurate } \\
\text { results and } \\
\text { check the } \\
\text { assignment on } \\
\text { same day. }\end{array}$ & $\begin{array}{l}\text { If student } \\
\text { perform the } \\
\text { practical with } \\
\text { accurate results } \\
\text { and does not } \\
\text { check the } \\
\text { assignment on } \\
\text { same day. }\end{array}$ & $\begin{array}{l}\text { If student } \\
\text { perform the } \\
\text { practical but not } \\
\text { obtain required } \\
\text { results. and } \\
\text { does not check } \\
\text { the assignment } \\
\text { on same day. }\end{array}$ & $\begin{array}{l}\text { If student } \\
\text { unable to finish } \\
\text { the experiment } \\
\text { on same day. }\end{array}$ & $\begin{array}{l}\text { If student is } \\
\text { absent for the } \\
\text { practical but he } \\
\text { completed his } \\
\text { practical in } \\
\text { extra hour. }\end{array}$ \\
\hline $\begin{array}{l}\text { Understanding of } \\
\text { assignment }\end{array}$ & $\begin{array}{l}\text { If student give } \\
5 \text { answer } \\
\text { correctly based } \\
\text { on practical. }\end{array}$ & $\begin{array}{l}\text { If student give } 4 \\
\text { answer } \\
\text { correctly based } \\
\text { on practical. }\end{array}$ & $\begin{array}{l}\text { If student give } 3 \\
\text { answer } \\
\text { correctly based } \\
\text { on practical. }\end{array}$ & $\begin{array}{l}\text { If student give } \\
2 \text { answer } \\
\text { correctly based } \\
\text { on practical. }\end{array}$ & $\begin{array}{l}\text { If student give } 1 \\
\text { answer } \\
\text { correctly based } \\
\text { on practical. }\end{array}$ \\
\hline $\begin{array}{l}\text { Presentation/clarity } \\
\text { of journal writing }\end{array}$ & $\begin{array}{l}\text { All the require } \\
\text { information } \\
\text { about the } \\
\text { practical is } \\
\text { written with the } \\
\text { neat sketch } \\
\text { diagram. }\end{array}$ & $\begin{array}{l}\text { All the require } \\
\text { information } \\
\text { about the } \\
\text { practical is } \\
\text { written without } \\
\text { the neat sketch } \\
\text { diagram. }\end{array}$ & $\begin{array}{l}\text { some require } \\
\text { information } \\
\text { about the } \\
\text { practical is } \\
\text { missing with } \\
\text { the neat sketch } \\
\text { diagram. }\end{array}$ & $\begin{array}{l}\text { some require } \\
\text { information } \\
\text { about the } \\
\text { practical is } \\
\text { missing without } \\
\text { the neat sketch } \\
\text { diagram. }\end{array}$ & $\begin{array}{l}\text { Handwriting is } \\
\text { not readable } \\
\text { and Diagram } \\
\text { are not correct }\end{array}$ \\
\hline
\end{tabular}

Date Created: July 24, 2019 


\section{Requirements for Implementing the tools}

The implementation of this tools is very easy, anyone with basic computer knowledge and prior knowledge of assessment methods can incorporate this tools in his classroom. The basic requirement for implementing this tools are:

- Computer with 32 bit or 64 bit operating system

- Minimum 100 Mbps Internet speed

- Smart phone to each student

- Prior knowledge to teacher of basic computer and assessment methods.

\section{Case Study of implementation of Edmodo}

Subject: Soft Skill (SE Production) AY 2017-18

Number of Student: 68

A. List of Assignment:

The different assignments have been given on Edmodo platform. Assignments generally based on videos, write-ups. Speech recording, resume competition etc.

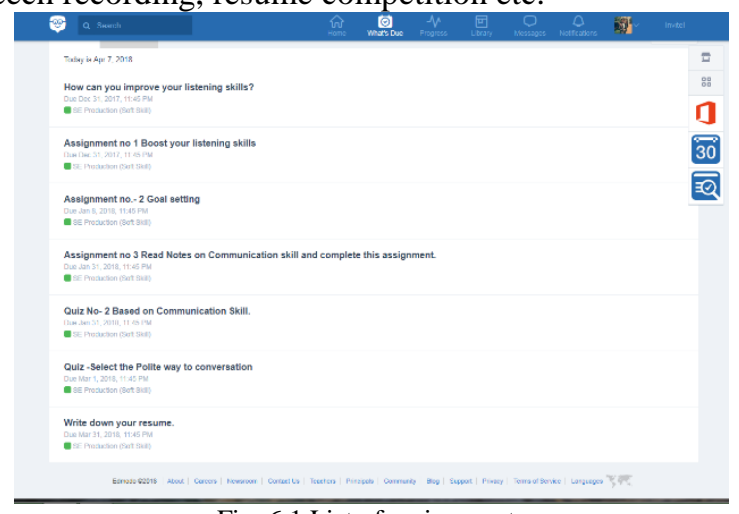

Fig. 6.1 List of assignments

B. Improvement in attainment

As students got the anytime accessible best material of subject on their phone with proper assessment, there is noticeable improvement in the PO attainment of Subject.

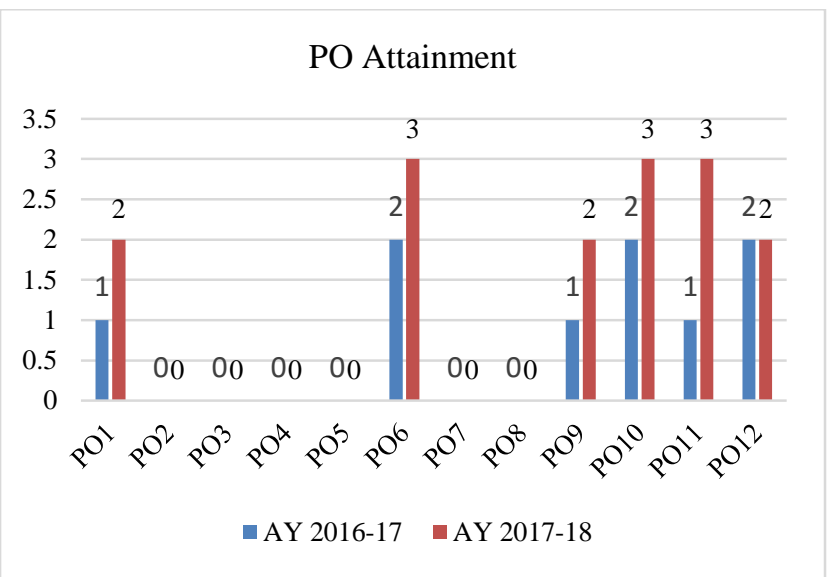

Fig. 6.2 Improvement in $\mathrm{PO}$ attainment

\section{Course exit survey}

To check the benefit of Edmodo in student's curriculum the course exit survey has been taken and the analysis of survey also indicate the use of Edmodo is beneficial for student in Soft skill subject to improve their skill. The following Questions are design to conduct the survey based on the assignments.

Table 1. Questions for course exit survey

\begin{tabular}{|c|l|}
\hline $\begin{array}{c}\text { Sr. } \\
\text { No }\end{array}$ & \multicolumn{1}{|c|}{ Question } \\
\hline 1) & $\begin{array}{l}\text { Are you able to understand importance of listening } \\
\text { skill? }\end{array}$ \\
\hline 2$)$ & $\begin{array}{l}\text { Are you able to set your long term, middle term, short } \\
\text { term goals of life? }\end{array}$ \\
\hline 3$)$ & $\begin{array}{l}\text { Are you able to adapt the polite way communication } \\
\text { and complaint? }\end{array}$ \\
\hline 4$)$ & $\begin{array}{l}\text { Are you able to write formal letters for different } \\
\text { scenario such as job application? }\end{array}$ \\
\hline 5$)$ & Are you able to write your professional resume? \\
\hline 6$)$ & $\begin{array}{l}\text { Are you able to know importance of body language } \\
\text { and interview etiquettes? }\end{array}$ \\
\hline
\end{tabular}

Table 2. Gradation policy

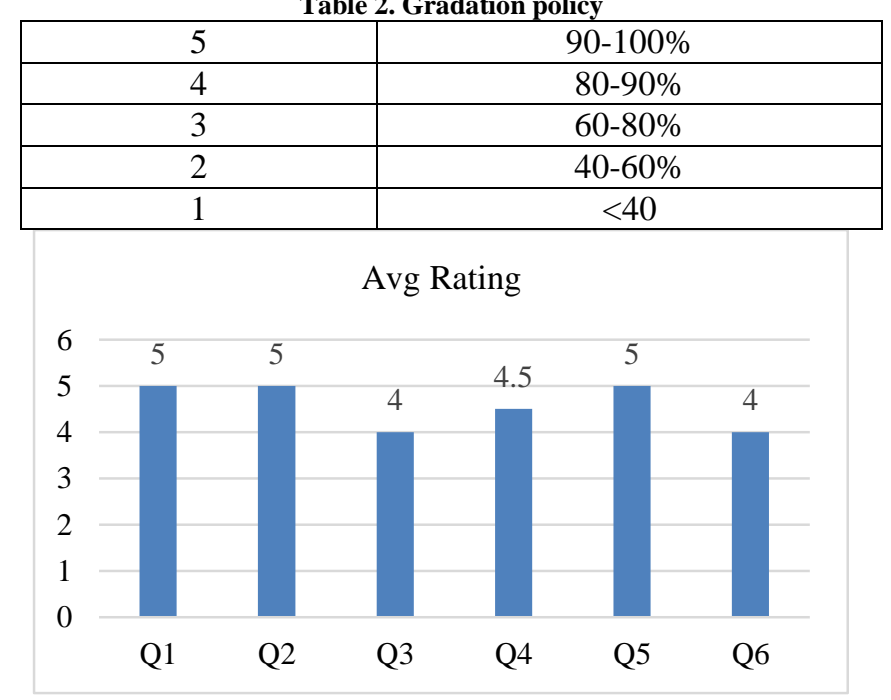

Fig. 6.3 Analysis of Course Exit survey

\section{Conclusions}

Assessment is a complex activity; meaningful, assessment requires effort on the part of the teacher and student. We can design assessment tasks that are easy to prepare and grade, or we can take the time to design an assessment that has intrinsic worth for both the student and the teacher. Eassessment offers a range of potential opportunities and advantages for teachers, students and institutions, including: Efficiency: Less time, Flexible delivery, Automatic processing response, Effective storage results and grades. Effectiveness: Immediate feedback, Analysis of question validity, new question types.

Authenticity: Access to people and resources, can be design to simulate the real world, can set complex task. 
Engagement: Multimodal formats, can use virtual world, can use self and peer review.

The quickest benefits to be gained using eassessments are associated with diagnostic and formative tasks which provide detailed and timely feedback for students to use in a subsequent task. By requiring students to complete assessment tasks early in the course, you can highlight the key concepts that students must understand in order to build new learning experiences.

\section{References}

D. Kavitha, D. Anitha (2018) Flipped classroom using ICT tools to improve the outcomes of the course soft computing- A case study, Journal of Engineering Education Transformation, 32(2), 39-45.

Benseman, J., \& Sutton, A. (2008) OECD/CERI Formative Assessment Project background report: New Zealand.

Crisp, G. (2012) Integrative assessment: Reframing assessment practice for current and future learning. Assessment and Evaluation in Higher Education, 37(1), 3343.
Dr. P. Venugapal Reddy (2018) Achieving academic excellence in private unaided engineering colleges in India, Journal of Engineering Education Transformation, 32(2), 100-104.

Ablin, J. A. (2008) Learning as problem design versus problem solving: Making the connection between cognitive neuroscience research and educational practice. Mind, Brain, and Education, 2(2), 52-54.

Abdul wahed, M., Nagy, Z. K., \& Blanchard, R. (2008) The Tri-Lab, a novel view of laboratory education Innovation, Good Practice and Research in Engineering Education. EE2008 Conference.

https://www.polleverywhere.com/ DOA: 09/11/2019

https://new.edmodo.com/home DOA: 09/11/2019

https://edpuzzle.com/ DOA: 09/11/2019

https://testmoz.com/ DOA: 09/11/2019

http://rubistar.4teachers.org/index.php DOA: 09/11/2019 